Article

\title{
Synthesis and Optimal Operation of Smart Microgrids Serving a Cluster of Buildings on a Campus with Centralized and Distributed Hybrid Renewable Energy Units
}

\author{
Daniele Testi * ${ }^{\circ}$, Paolo Conti ${ }^{[}$, Eva Schito ${ }^{\circledR}$, Luca Urbanucci ${ }^{\circledR}$ and Francesco $D^{\prime}$ Ettorre \\ DESTEC (Department of Energy Engineering), University of Pisa, 56122 Pisa, Italy; paolo.conti@unipi.it (P.C.); \\ eva.schito@for.unipi.it (E.S.); luca.urbanucci@ing.unipi.it (L.U.); f.dettorre@studenti.unipi.it (F.D.) \\ * Correspondence: daniele.testi@unipi.it; Tel.: +39-050-2217109
}

Received: 30 December 2018; Accepted: 20 February 2019; Published: 23 February 2019

check for updates

\begin{abstract}
Micro-district heating networks based on cogeneration plants and renewable energy technologies are considered efficient, viable and environmentally-friendly solutions to realizing smart multi-energy microgrids. Nonetheless, the energy production from renewable sources is intermittent and stochastic, and cogeneration units are characterized by fixed power-to-heat ratios, which are incompatible with fluctuating thermal and electric demands. These drawbacks can be partially overcome by smart operational controls that are capable of maximizing the energy system performance. Moreover, electrically driven heat pumps may add flexibility to the system, by shifting thermal loads into electric loads. In this paper, a novel configuration for smart multi-energy microgrids, which combines centralized and distributed energy units is proposed. A centralized cogeneration system, consisting of an internal combustion engine is connected to a micro-district heating network. Distributed electric heat pumps assist the thermal production at the building level, giving operational flexibility to the system and supporting the integration of renewable energy technologies, i.e., wind turbines, photovoltaic panels, and solar thermal collectors. The proposed configuration was tested in a hypothetical case study, namely, a University Campus located in Trieste, Italy. The system operation is based on a cost-optimal control strategy and the effect of the size of the cogeneration unit and heat pumps was investigated. A comparison with a conventional configuration, without distributed heat pumps, was also performed. The results show that the proposed configuration outperformed the conventional one, leading to a total-cost saving of around $8 \%$, a carbon emission reduction of $11 \%$, and a primary energy saving of $8 \%$.
\end{abstract}

Keywords: energy microgrids; energy system integration; energy system optimization; smart building clusters; hybrid renewable systems; heat pumps; district heating; cogeneration

\section{Introduction}

Cogeneration of useful heat and electrical power for an urban district or a cluster of buildings is a technically mature, environmentally-friendly and cost-effective solution, supported by the European Union Directive [1] on energy efficiency, together with the use of renewable energy sources (RES). Indeed, the Directive [2] on energy performance of buildings indicates four high-efficiency technologies, whose feasibility should be evaluated prior to construction of any new building: (a) decentralized energy supply systems based on RES; (b) cogeneration; (c) district or block heating or cooling; and (d) heat pumps.

In view of this, several different configurations of distributed energy systems (DES) have been investigated in recent years, mostly focusing on cogeneration units and RES technologies. Pagliarini 
and Ranieri [3] studied the effectiveness of thermal storage coupled with a cogeneration engine to satisfy the energy requirements of a university campus, and stressed the importance of the sizing of the storage. Bracco et al. [4] dealt with the topic of distributed generation, by presenting the University of Genoa polygeneration microgrid, which is based on RES and cogeneration units. A tool for the optimal integrated design and operation of a trigeneration system serving a cluster of buildings was proposed by Piacentino et al. [5,6]. The optimal design and operation of a hybrid renewable energy system based on an internal combustion engine and photovoltaic panels was investigated by Destro et al. [7].

In addition to the synthesis and design problems, the optimal operational strategy of energy microgrids has also received considerable attention. Indeed, the adoption of smart control techniques can significantly improve the economic and environmental performances of those systems [8]. For example, Roldán-Blay et al. [9] developed an algorithm for the optimal management of a RES-based electric microgrid. Similarly, Phan et al. [10] investigated schedule strategies to minimize the operating cost of a building energy system with photovoltaic panels and a wind micro-turbine. Asaleye et al. [11] proposed a decision-support tool that identifies the optimal operation of renewable energy microgrids by considering forecast of climate variables.

All the above-mentioned works show the energy, environmental and economic effectiveness of cogeneration systems and renewable energy technologies in smart energy grids. Nevertheless, some unresolved issues remain. Indeed, the intermittent and stochastic nature of RES limits their use, and cogeneration units are characterized by a fixed power-to-heat ratio, thus, they fail to match both fluctuating thermal and electric demands. In this context, electrically driven heat pumps may represent an interesting solution due to their ability to shift thermal loads into electric loads. Moreover, heat pumps are a mature and efficient technology, and they are especially suited to the implementation of smart control strategies [12].

For those reasons, the present work discusses a novel configuration for smart multi-energy microgrids, which consists of distributed energy units and a centralized cogeneration unit feeding a micro-district heating network. Specifically, we investigate the benefits of integrating reversible heat pumps for heating and cooling purposes at the building level. The heat pumps represent an interconnection between the electricity and heating networks, therefore, they can be used to increase the operational flexibility of the microgrid and support the integration of renewable energy technologies, i.e., wind turbine, photovoltaic panels, and solar thermal collectors.

The paper is structured as follows. Section 2 presents the design and modeling methodology of the smart multi-energy microgrid. Sections 3 and 4 present the case study and the optimization problem and methodology, which are used in Section 5 to compare the proposed configuration using distributed heat pumps, with a more conventional solution that employs a centralized CHP (Combined Heat and Power) system and natural-gas boilers. Finally, Section 6 presents the concluding remarks.

\section{Energy System Overview and Modeling}

In this work, we refer to multi-energy microgrids of medium dimensions with different buildings and loads, using an integrated thermal and electrical energy production system fed by traditional and renewable sources to concurrently satisfy various services (heating, cooling, electrical energy and domestic hot water). The considered generators are: (i) a CHP consisting in an internal combustion engine (ICE); (ii) natural gas boilers; (iii) heat pumps and chillers; (iv) solar thermal collectors; (v) wind turbines; and (vi) photovoltaic modules. Thermal storage is also considered. Figure 1 shows a simplified classification scheme of the reference energy system.

As is well-known, the traditional design approach based on a separate analysis of each component represents a suboptimal design method for multi-energy systems [13]. The so-called simulation-based optimization methods are the most recognized procedures to investigate the best synthesis, sizing and control of integrated system through the simulation of the operative performances. Therefore, in the following sub-section we present the operative dynamic model of each block listed in Figure 1. 


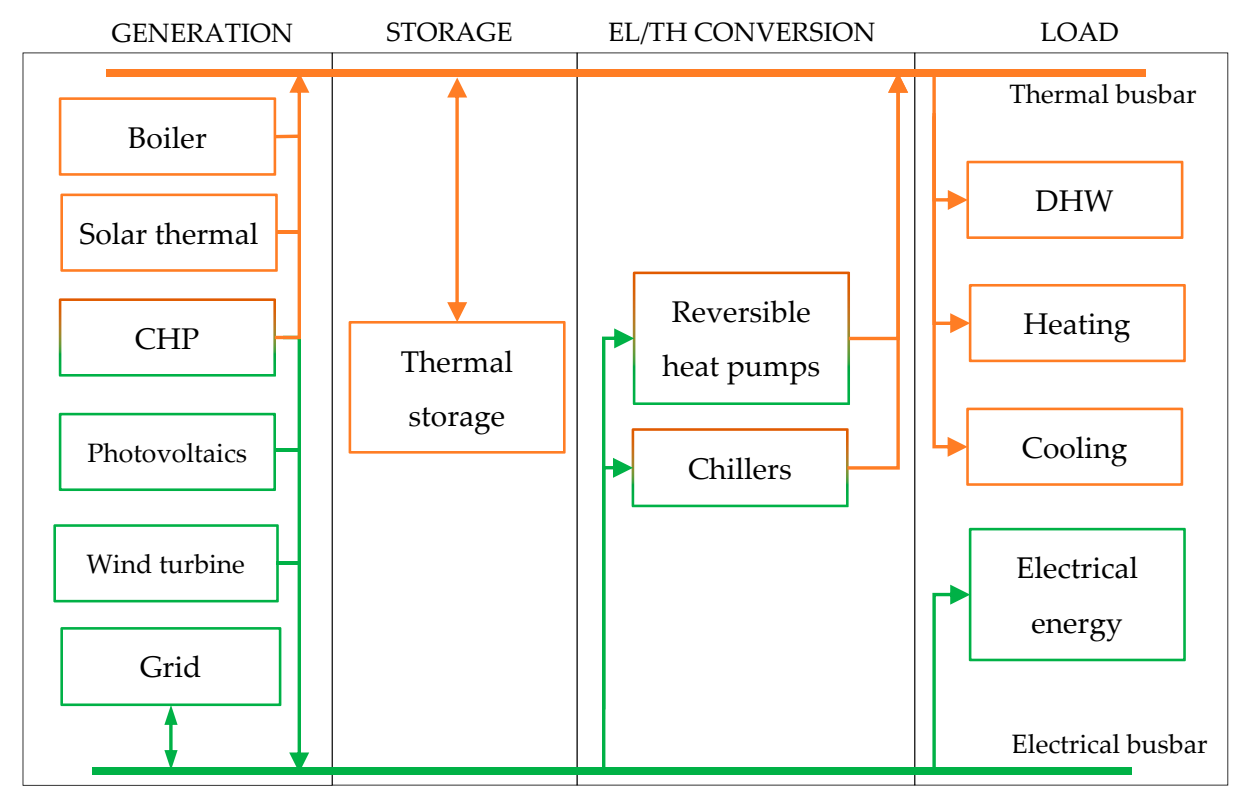

Figure 1. Schematic of the energy system.

Modeling of the System Components

The components models must be based on a proper trade-off between the accuracy of the results and computational effort. The latter feature is essential to allow their employment within the optimization procedure to identify the most efficient design and operation of the smart multi-energy microgrid.

The ICE is modeled through performance curves taken from [14], which provide the thermal and electric efficiency, $\eta_{e l}$ and $\eta_{t h}$, respectively, as a function of the engine load factor $L_{I C E}$. The electric $\left(E_{I C E}\right)$ and thermal $\left(Q_{I C E}\right)$ output are evaluated based on the load factor, $L_{I C E}$, and the ICE nominal electric power capacity $\left(E_{I C E}^{\text {nom }}\right)$, as follows:

$$
\left\{\begin{array}{c}
E_{I C E}=E_{I C E}^{n o m} \cdot L_{I C E} \\
Q_{I C E}=\left[\eta_{t h}\left(L_{I C E}\right) / \eta_{e l}\left(L_{I C E}\right)\right] \cdot E_{I C E}^{\text {nom }} \cdot L_{I C E}
\end{array}\right.
$$

The boilers can be modeled with a constant efficiency $\left(\eta_{B}\right)$ over their whole operating range. Photovoltaic panels are simulated through the model provided by [15], which considers the PV performance as a function of the solar irradiance, PV characteristics and cell array temperature:

$$
\begin{gathered}
E_{P V}=n_{P V} S_{P V} \eta_{P V} \eta_{i n v} I_{\text {sol }, P V} \\
\eta_{P V}=\eta_{P V, r e f}\left[1-\beta_{T, P V}\left(T_{P V}-T_{P V, r e f}\right)\right] \\
T_{P V}=T_{\text {ext }}+\left(219+819 K_{t}\right) \frac{N O C T-20}{200}
\end{gathered}
$$

The thermal performances of the ST are evaluated through the classical model illustrated in [16], based on the characteristics of the panel in terms of transmittance and absorptance factors for normal irradiance $\left(<\tau \alpha>_{n}\right)$, removal factor $\left(F_{r}\right)$ and frontal losses $\left(U_{l}\right)$. The equations read:

$$
\begin{gathered}
\eta_{S T}=F_{r}(\tau \alpha)_{n}\left[1-b_{0}\left(\frac{1}{\cos \theta}-1\right)\right]-\frac{F_{r} U_{L}\left(T_{S T, i n}-T_{e x t}\right)}{I_{\text {sol }, S T}} \\
Q_{S T}=n_{S T} S_{S T} \eta_{S T} I_{S o l, S T}
\end{gathered}
$$


The electrical power generated by the wind turbine varies as the cube of the wind speed, between a cut-in speed and a nominal speed; the latter corresponds to the nominal electrical power generated by the wind turbine. The nominal electrical power is generated between the nominal wind speed and a cut-out speed. The equations, in accordance with [17], read:

$$
E_{W T}=\left\{\begin{aligned}
0, & w\left\langle w_{\text {cut }- \text { in }} \text { or } w\right\rangle w_{\text {cut }- \text { out }} \\
k w^{3}, & w_{\text {cut-in }} \leq w \leq w_{\text {nom }} \\
k w_{\text {nom }}^{3}, & w_{\text {nom }} \leq w \leq w_{\text {cut }- \text { out }}
\end{aligned}\right.
$$

where $k$ is a coefficient that depends on the characteristic curve of the generator.

The internal energy variation in the thermal storage is calculated considering the thermal fluxes provided to the water volume from all the connected generators and the heat delivered to the load:

$$
V_{T S} \rho_{W}{ }_{W} \Delta T_{T S}=\sum_{i} Q_{T S, i n, i}-\sum_{j} Q_{T S, o u t, j}-Q_{T S, l s}
$$

where the heat losses of the storage tank are evaluated as

$$
Q_{T S, l s}=U A_{T S}\left(T_{T S}-T_{\text {ext,TS }}\right)
$$

Reversible heat pumps and chiller performance are evaluated by means of the so-called second-law efficiency [18]. The method reads:

$$
\begin{aligned}
& C O P=\eta_{H}^{I I} \cdot C O P_{i d}=\eta_{H}^{I I} \frac{T_{\text {cond }}}{T_{\text {cond }}-T_{\text {eva }}} \\
& E E R=\eta_{C}^{I I} \cdot E E R_{i d}=\eta_{H}^{I I} \frac{T_{\text {eva }}}{T_{\text {cond }}-T_{\text {eva }}}
\end{aligned}
$$

where $C O P_{i d}$ and $E E R_{i d}$ are the coefficients of performance of a reversed Carnot cycle operating between the source and sink temperatures. According to manufacturers, both $\eta_{H}^{I I}$ and $\eta_{C}^{I I}$ can be assumed as constant.

The generators are connected to the thermal storages and the buildings through a district heating network (DHN), whose heat losses can be modeled as follows:

$$
Q_{D H N, l s}=U_{D H N} L_{D H N}\left(T_{a v g, D H N}-T_{\text {ground }}\right)
$$

Finally, the heating/cooling loads of the buildings can be evaluated through a model that correlates the sol-air temperature [19] with the energy load of the building, based on the standard EN 15306 [20]. This model is further improved by considering the effect of the building thermo-physical properties in shifting the influence of the external climate on the heating/cooling load.

$$
\begin{gathered}
Q_{t h, H / C}=P_{H / C}\left(1-\frac{\overline{T_{e x t}^{*}}-T_{\text {des }, H / C}}{T_{o f f, H / C}-T_{d e s, H / C}^{*}}\right) \\
\overline{T_{\text {ext }}^{*}}(t)=\frac{1}{\bar{\phi}} \sum_{i=0}^{\bar{\phi}} T_{\text {ext }}^{*}(t-\bar{\phi}+i) \\
\bar{\phi}=\sum_{i} \frac{(U A)_{i} \phi_{i}}{\left[\sum_{i}(U A)_{i}+H_{v e}\right]} \\
T_{\text {ext }}^{*}(t)=T_{\text {ext }}(t)+\frac{\alpha_{S}}{h_{e}} I_{\text {sol }}(t)
\end{gathered}
$$


Further details on Equations (13)-(16) can be found in [21]. This model represents a good trade-off between simplified models (e.g., the energy signature method [22]), which simply correlates external temperature and heating/cooling load, and dynamic models (e.g., TRNSYS or EnergyPlus), which include the building inertia characteristics, solar radiation, and internal loads, providing more accurate results, but requiring a detailed knowledge of the building envelope and heat gain profiles.

\section{Case Study}

In this work, we refer to an integrated energy system serving a hypothetical campus, located in Trieste, Italy. This city has a favorable climate, where RES (solar thermal, photovoltaic modules, wind turbines) can provide a significant amount of energy. The Italian Thermotechnical Committee (CTI) provides hourly profiles of external temperature, global solar irradiance on the horizontal plane and wind speed [23]. The monthly-average values of the external temperature and irradiance on horizontal plane are reported in Figure 2.

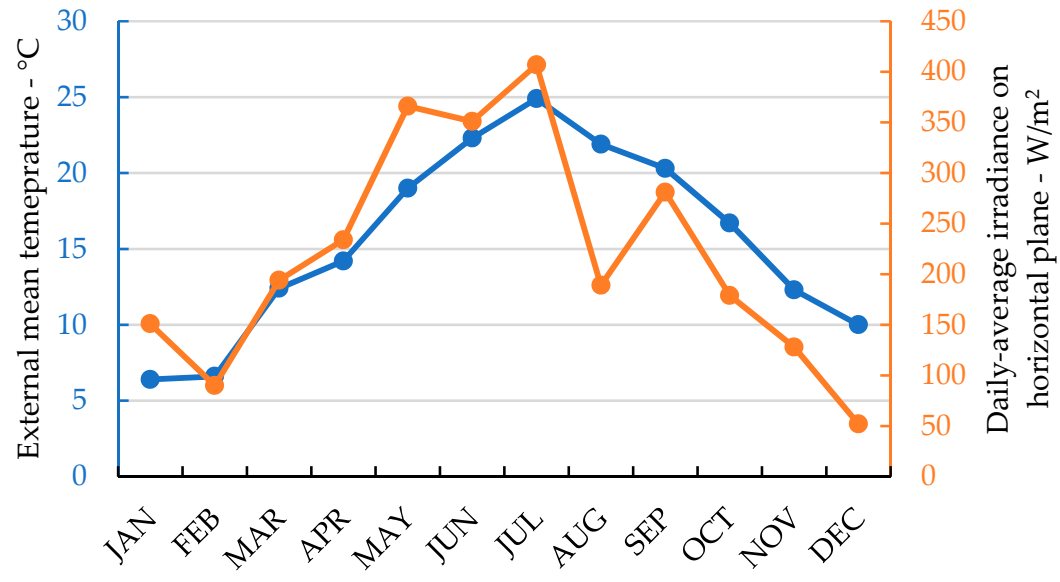

Figure 2. Average monthly temperature and daily irradiance on horizontal plane.

The campus is located far enough from the city to avoid airflow obstructions and shading, which would reduce the renewable energy share. As a whole, the 1000-student campus occupies a surface of $1 \times 0.5 \mathrm{~km}^{2}$ and includes five dormitories, a dining hall, a gym, a students' center with classrooms and administrative offices. A schematic representation of the campus is shown in Figure 3.

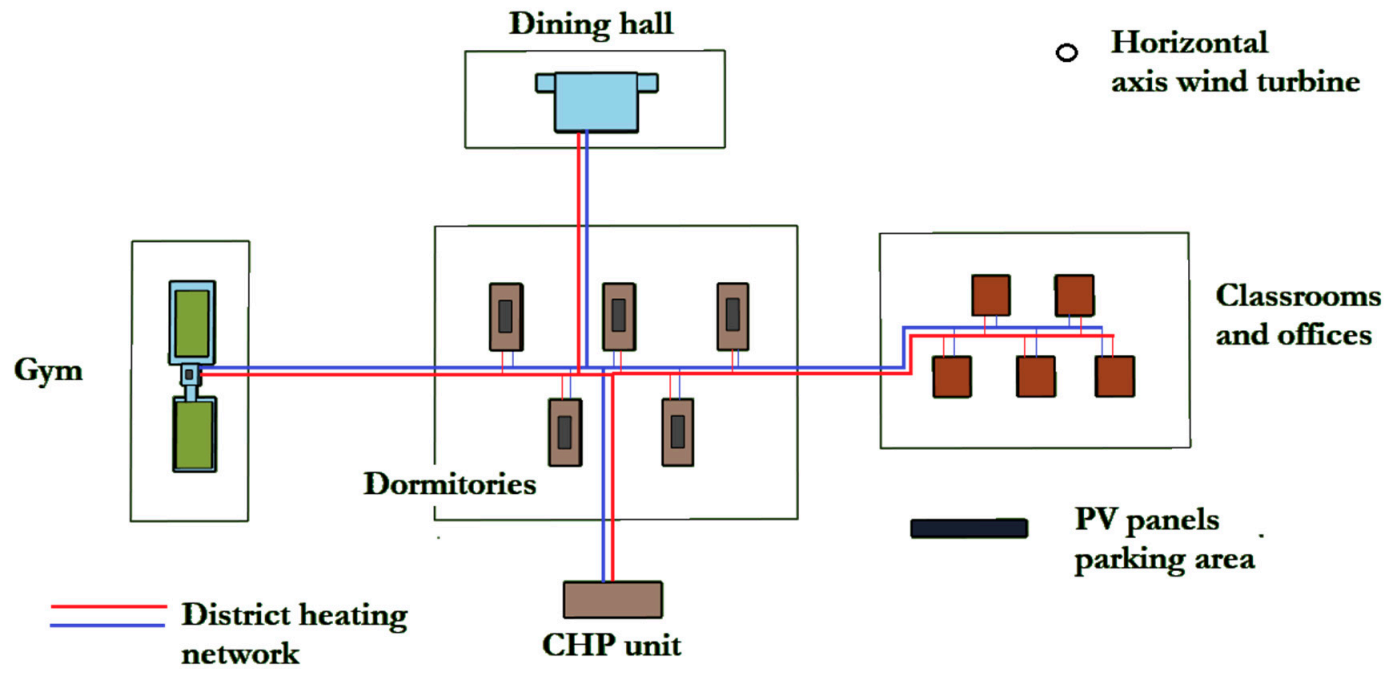

Figure 3. Scale representation of the campus: buildings, district heating, and generation systems. 
All the buildings have a similar structure in terms of thermal transmittance of the walls, roofs, floors, and windows $\left(0.29 \mathrm{~W} / \mathrm{m}^{2} \cdot \mathrm{K}, 0.19 \mathrm{~W} / \mathrm{m}^{2} \cdot \mathrm{K}, 0.26 \mathrm{~W} / \mathrm{m}^{2} \cdot \mathrm{K}, 1.80 \mathrm{~W} / \mathrm{m}^{2} \cdot \mathrm{K}\right.$, respectively). Specific profiles of internal gains and electrical energy requirements were chosen for each building type, according to their use, periods of presence, and appliances. The internal gains and electrical energy requirements have lower values during weekends and holidays. The buildings have different terminal units that require two supply temperature levels (i.e., low and medium). The power peak and total energy for the heating, cooling, domestic hot water (DHW) and electrical energy services are reported in Table 1.

Table 1. Peak values and energy needs for the four services of the campus and for the five types of buildings.

\begin{tabular}{cccccc}
\hline Tag & Dormitories & Gym & Offices & Dining Hall & Classrooms \\
\hline Total floor surface, $\mathrm{m}^{2}$ & $\begin{array}{c}\text { 10,800 } \\
\text { Radiant panels } \\
\text { (Low-temp) }\end{array}$ & $\begin{array}{c}\text { Fancoils } \\
\text { (Mid-temp) }\end{array}$ & $\begin{array}{c}\text { Fancoils } \\
\text { (Mid-temp) }\end{array}$ & $\begin{array}{c}\text { Fancoils } \\
\text { (Mid-temp) }\end{array}$ & $\begin{array}{c}\text { Fancoils } \\
\text { (Mid-temp) }\end{array}$ \\
Terminal units & 140 & 6 & 20 & 54 & 25 \\
Heating load, $\mathrm{kW}$ & 214 & 6 & 22 & 72 & 29 \\
Heating demand, MWh & 71 & 12 & 32 & 65 & 114 \\
Cooling load, $\mathrm{kW}$ & 19 & 4 & 24 & 33 & 108 \\
Cooling demand, MWh & 81 & 54 & 0 & 0 & 0 \\
DHW load, $\mathrm{kW}$ & 109 & 75 & 0 & 0 & 0 \\
DHW demand, MWh & 50 & 10 & 20 & 20 & 20 \\
Power load, $\mathrm{kW}$ & 223 & 45 & 90 & 90 & 90 \\
Power demand, MWh & & & &
\end{tabular}

In this work, we compare a "centralized" configuration (see Figure 4a), in which the DHN is fed by a cogeneration unit and a centralized gas boiler, with a "distributed" one (see Figure 4b), in which reversible heat pumps are installed in the buildings. In both configurations, the sizing of the solar and wind generators remains the same, while an optimization analysis is performed for the CHP and heat pumps, together with the optimal control strategy (see Section 4).

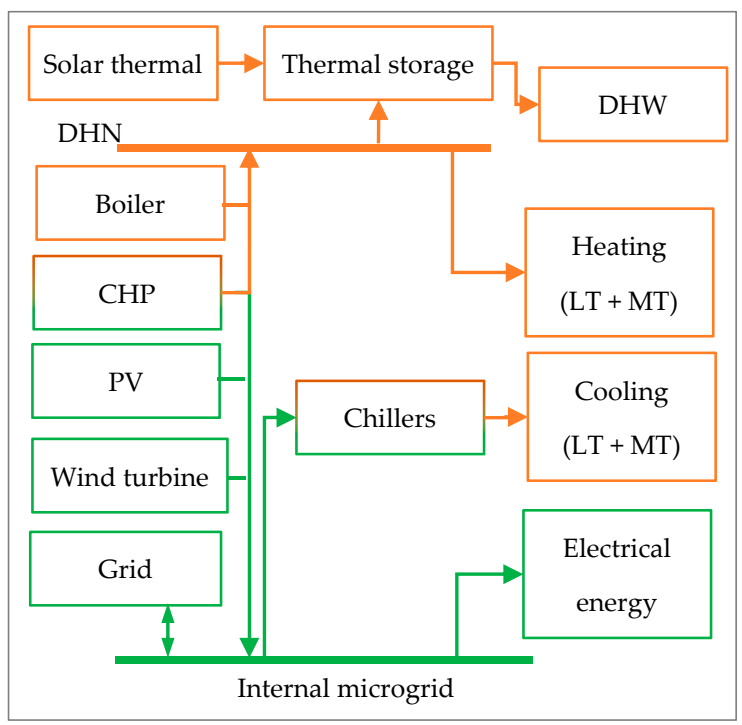

(a)

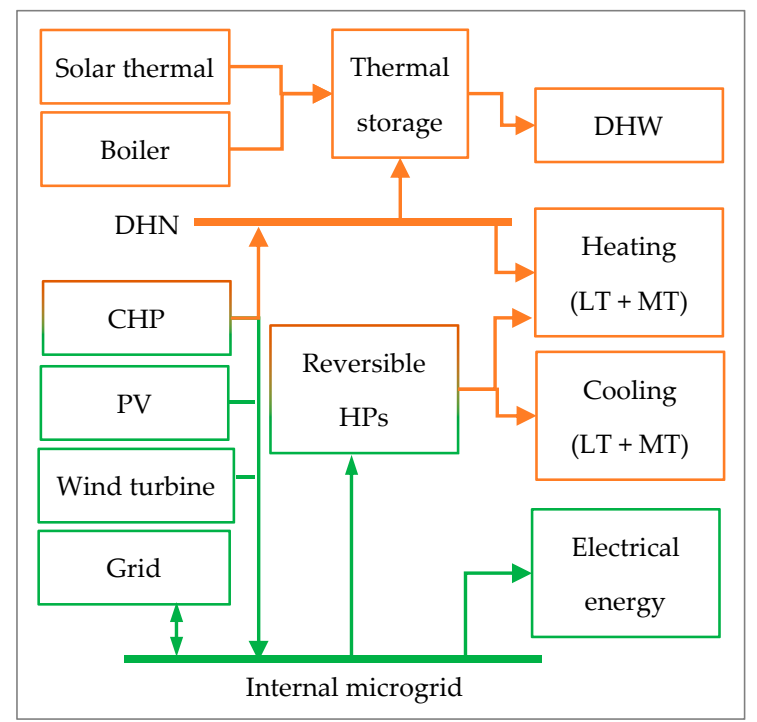

(b)

Figure 4. Analyzed configuration for the reference multi-energy microgrid: (a) centralized, (b) distributed.

The generators concur to satisfy the heating/cooling/DHW/electrical energy requirements of the campus with the following strategy: 
- The electrical demand consists of the energy input of the electrical appliances, DHN circulation pumps, and heat pumps or chillers. Electrical energy is purchased from the grid $\left(E_{P}\right)$ when the power generated by the photovoltaic modules $\left(E_{P V}\right)$, the wind turbine $\left(E_{W T}\right)$ and ICE (EICE) is not sufficient to satisfy the requirements. On the contrary, if the electrical production is higher than loads, the overproduction is sold to the grid $\left(E_{S}\right)$.

- $\quad$ The DHW service $\left(Q_{H T, D}\right)$ is required only for dormitories and the gym. The thermal storages are heated by the solar thermal panels $\left(Q_{S T}\right)$, and by the DHN or back-up boilers $\left(Q_{B}\right)$ when the temperature drops below the setpoint value (i.e., $55^{\circ} \mathrm{C}$ ). In the centralized configuration, the DHN represents the back-up generator, while in the distributed configuration both DHN or local boilers can be used (see Figure 4). The thermal storages are only used for the DHW service.

- The heating service is required at two different levels of temperature (low and medium, $Q_{L T, D}$ and $\left.Q_{M T, D}\right)$. In the centralized configuration, it is delivered by the DHN, in the distributed layout it is provided by the DHN or by the local heat pumps $\left(Q_{H P}\right)$.

- Also, the cooling service is required at two different levels of temperature $\left(C_{L T, D}\right.$ cooling requirement through radiant panels, $C_{M T, D}$ cooling requirement through fan-coils). In the centralized configuration, air-to-water electrically-driven chillers are used whereas in the distributed configuration, reversible heat pumps are used.

- In the distributed configuration, the reversible heat pumps are in the buildings and provide both heating and cooling service at all temperature levels.

Table 2 reports all the parameters of the analyzed smart multi-energy microgrid.

Table 2. Parameters used in the analysis.

\begin{tabular}{|c|c|c|c|c|c|}
\hline Parameter & Value & Parameter & Value & Parameter & Value \\
\hline PV collectors Number & 800 & ST panels Number & 30 & $\begin{array}{l}\text { Building Time } \\
\text { shift, } \bar{\phi}\end{array}$ & $3 \mathrm{~h}$ \\
\hline PV Single surface, $S_{P V}$ & $1.5 \mathrm{~m}^{2}$ & ST Single surface, $\mathrm{S}_{\mathrm{ST}}$ & $3 \mathrm{~m}^{2}$ & $\begin{array}{l}\text { Supply heating } \\
\text { temperatures }\end{array}$ & $\begin{array}{l}\text { MT: } 45^{\circ} \mathrm{C} \\
\text { LT: } 35^{\circ} \mathrm{C}\end{array}$ \\
\hline PV coefficient, $\beta_{T, P V}$ & $0.507 \% / \mathrm{K}$ & ST Removal factor, $F_{R}$ & 0.8 & $\begin{array}{l}\text { Supply cooling } \\
\text { temperatures }\end{array}$ & $\begin{array}{l}\text { MT: } 15^{\circ} \mathrm{C} \\
\text { LT: } 7^{\circ} \mathrm{C}\end{array}$ \\
\hline $\begin{array}{l}\text { PV Reference operational } \\
\text { temperature, } \boldsymbol{T}_{\text {ref, } P V}\end{array}$ & $25^{\circ} \mathrm{C}$ & ST Frontal losses, $\mathrm{U}_{\mathrm{L}}$ & $5 \mathrm{~W} /\left(\mathrm{m}^{2} \cdot \mathrm{K}\right)$ & 1 & \\
\hline $\begin{array}{l}\text { Overall efficiency of the PV } \\
\text { electronic converter, } \eta_{i n v}\end{array}$ & 0.90 & $\mathrm{ST}(\tau \boldsymbol{\alpha})_{n}$ & 0.7 & & \\
\hline $\begin{array}{l}\text { PV Nominal operation cell } \\
\text { temperature } N O C T_{P V T}\end{array}$ & $45^{\circ} \mathrm{C}$ & ST angle modifier, $\mathrm{b}_{0}$ & 0.1 & & \\
\hline $\begin{array}{l}\text { Wind turbine } \\
\text { Capacity, } P_{W T, \text { nom }}\end{array}$ & $150 \mathrm{~kW}$ & $\begin{array}{l}\text { Reversible HPs Second-law } \\
\text { efficiency, } \eta_{H / C}^{I I}\end{array}$ & $0.4 / 0.35$ & $\begin{array}{c}\text { DHN } \\
\text { Length, } L_{D H N}\end{array}$ & $1750 \mathrm{~m}$ \\
\hline WT Nominal speed, $w_{\text {nom }}$ & $12 \mathrm{~m} / \mathrm{s}$ & $\begin{array}{c}\text { Thermal storage } \\
\text { Volume, } V_{T S}\end{array}$ & $20 \mathrm{~m}^{3}$ & $\begin{array}{c}\text { DHN Loss } \\
\text { coefficient, } U_{D H N}\end{array}$ & $\begin{array}{c}0.15 \\
\mathrm{~W} /(\mathrm{m} \cdot \mathrm{K})\end{array}$ \\
\hline WT Cut-in speed, $w_{\text {cut-in }}$ & $3.5 \mathrm{~m} / \mathrm{s}$ & TS Loss coefficient, $U A_{T S}$ & $0.02 \mathrm{~W} / \mathrm{K}$ & Ground temp, $T_{g}$ & $15.6^{\circ} \mathrm{C}$ \\
\hline WT Cut-out speed, $w_{\text {cut-out }}$ & $20 \mathrm{~m} / \mathrm{s}$ & TS Set point & $55^{\circ} \mathrm{C}$ & - & - \\
\hline Boiler efficiency, $\eta_{b}$ & 0.90 & TS Maximum temperature & $90{ }^{\circ} \mathrm{C}$ & - & - \\
\hline
\end{tabular}

\section{Optimization Problem and Methodology}

In this work, we aim to compare the centralized and the distributed configurations defined in Section 3, from an economical point of view. The selected performance index is the annual total cost, $T C$, defined as:

$$
T C=\frac{I N V}{t_{\text {life }}}+O \& M+O C
$$

where $I N V / t_{l i f e}, O \& M$, and $O C$ are the yearly capital, maintenance, and energy operational costs, respectively, and $t_{\text {life }}$ is the considered lifetime of the microgrid (i.e., 20 years). Since we are making a comparative analysis, TC only includes the costs that differ in the two configurations, i.e., the purchased equipment cost (PEC) for the ICE unit, reversible HPs, chillers, and boilers, the associated operations and maintenance costs $(\mathrm{O} \& \mathrm{M})$, and the net cost of the energy purchased from the gas and power grids. 
We do not consider the sizing of the RES technologies, which are assumed to have the same design and energy production in both the distributed and centralized configurations; therefore, they are not included in the economic analysis and optimization process. The terms in Equation (17) read:

$$
\begin{gathered}
I N V=P E C_{I C E}+P E C_{H P}+P E C_{C}+P E C_{B} \\
O \& M=O \& M_{I C E}+O \& M_{H P}+O \& M_{C}+O \& M_{B} \\
O C=\sum_{i}^{8760} O C^{i}=\sum_{i=1}^{8760}\left(c_{F}^{i} F_{B}^{i}+c_{F}^{i} F_{I C E}^{i}+c_{e l, P}^{i} E_{P}^{i}-c_{e l, S}^{i} E_{S}^{i}\right)
\end{gathered}
$$

The timestep length adopted for the energy system simulation is one hour. The investment and maintenance cost functions are presented in Table 3. The costs of HPs, chillers and boilers were

\begin{tabular}{|c|c|c|c|}
\hline Generator & $\operatorname{PEC}(€)$ & O\&M (€) & References \\
\hline ICE & $7789\left(E_{I C E}^{n o m}\right)^{0.6}$ & $0.015 \cdot \sum^{8760}\left(E_{I C E}^{i}\right)$ & [24-26] \\
\hline HPs & $206 Q_{H P}^{n o m}+10,000$ & $0.02 \cdot \stackrel{i}{P E C_{H P}}$ & {$[27,28]$} \\
\hline Chillers & $206 Q_{C}^{\text {nom }}+3824$ & $0.02 \cdot P E C_{C}$ & Manufacturers data and [27] \\
\hline Boilers & $56 \widetilde{Q}_{B}^{n o m}+2222$ & $0.02 \cdot P E C_{B}$ & Manufacturers data and $[27,28]$ \\
\hline
\end{tabular}
obtained through a linear regression of actual manufacturers' data.

Table 3. Cost functions.

According to the operating strategy described in Section 3, both the sizing and control optimization can be written as a function of the ICE nominal electrical capacity, $E_{I C E}^{n o m}$, and load factor profile, $L_{I C E}^{i}$.

1. We assumed a set of 201 possible values of $E_{I C E}^{\text {nom }}$ in the range between 0 and $1000 \mathrm{~kW}_{\mathrm{el}}$, namely, $E_{I C E, n}^{n o m} \in\{0,5,10 \ldots 995,1000\} \quad n=1,2,3 \ldots 201$

2. For each $n$-th ICE size, an exhaustive search is performed to find the ICE load factor, $L_{I C E, j^{\prime}}^{i}$ which minimizes the operational energy cost at any $i$-th timestep, $O C^{i}$, (i.e., control optimization). Further details on this point are provided in Section 4.1.

3. The optimal $L_{I C E, n}^{i}$ sequence determines the thermal and electrical output profiles of the ICE. Subsequently, also the other generators output can be easily found as the residual load. The maximum output times a precautionary factor of 1.1 gives the nominal capacity of each generator.

4. Capital and annual maintenance costs are evaluated for any $n$-th sizing and corresponding optimal control sequence. Then, the total annual cost is evaluated.

5. Finally, we selected the best sizing and corresponding control strategy as the one with the minimum total annual cost, evaluated at point 4 .

\subsection{Operational Optimization Problem}

The operational optimization problem consists in identifying the scheduling of the generators that meets the energy demands at minimum cost (i.e., cost for purchasing electricity from the grid, income for selling electricity to the grid, cost of natural gas). The operational optimization problem is therefore defined as the minimization of the total annual energy cost.

$$
\min \{T C\}=\min \left\{\sum_{i=1}^{8760} c_{F}^{i} F_{B}^{i}+\sum_{i=1}^{8760} c_{F}^{i} F_{I C E}^{i}+\sum_{i=1}^{8760}+c_{e l, P}^{i} E_{P}^{i}-\sum_{i=1}^{8760} c_{e l, S}^{i} E_{S}^{i}\right\}
$$

where $i=1, \ldots, 8760$ timesteps, $c_{F}$ is the fuel price $(0.04 € / \mathrm{kWh})$, and $c_{e l, P}$ and $c_{e l, S}$ are the prices of purchased and sold electricity $(0.18$ and $0.04 € / \mathrm{kWh})$, respectively. Consequently, the following decision variables are considered: 


$$
E_{I C E}^{i}, Q_{I C E}^{i}, Q_{B, j}^{i}, Q_{H P, L T, k}^{i}, Q_{H P, M T, k}^{i}, C_{C, L T, k}^{i}, C_{C, M T, k}^{i}, E_{S}^{i}, E_{P}^{i} .
$$

and demand constraints and balance equations and inequalities are defined as follows

$$
\begin{gathered}
Q_{D H N, H T, j}^{i}+Q_{B, j}^{i}-Q_{H T, n e t D, j}^{i}=0 \\
Q_{D H N, M T, k}^{i}+Q_{H P, M T, k}^{i}-Q_{M T, D, k}^{i}=0 \\
Q_{D H N, L T, k}^{i}+Q_{H P, L T, k}^{i}-Q_{L T, D, k}^{i}=0 \\
Q_{I C E}^{i}-Q_{D H N, l s}^{i}-\sum_{j} Q_{D H N, H T, j}^{i}-\sum_{k} Q_{D H N, M T, k}^{i}-\sum_{k} Q_{D H N, L T, k}^{i} \geq 0 \\
C_{C, L T, k}^{i}-C_{L T, D, k}^{i}=0 \\
C_{C, M T, k}^{i}-C_{M T, D, k}^{i}=0 \\
E_{P}^{i}-E_{S}^{i}-\sum_{k} E_{H P, k}^{i}-\sum_{k} E_{C, k}^{i}+E_{I C E}^{i}+E_{P V}^{i}+E_{W I N D}^{i}-E_{D}^{i}-E_{a u x}^{i}=0
\end{gathered}
$$

To solve the optimal operation problem, an ad-hoc dispatch strategy algorithm has been developed, based on the following considerations:

- the problem can be considered "static";

- three orders of priority must be considered for the DHN dispatch.

Indeed, in the energy system under investigation, the overall optimum coincides with the sum of optimums of every single timestep, since the behavior of the TSs (Thermal Storages) linked to the solar thermal is independent from the operational control. For this reason, as already shown in [29], the overall operational problem can be split into 8760 subproblems, one for each timestep, and the problem can be considered "static". Moreover, the DHN must always satisfy with higher priority the medium-temperature heat demand $Q_{M T, D^{\prime}}^{i}$, as opposed to the low-temperature heat demand $Q_{L T, D^{\prime}}^{i}$ since the HPs operate with higher COP at lower supply temperatures. Therefore, only the three following combinations must be evaluated:

(1) HT-MT-LT

(2) MT-HT-LT

(3) MT-LT-HT

For each possible dispatch priority, once the $L_{I C E}$ is set and the amount of electricity and heat produced by the ICE is defined, the thermal losses and the net amount of heat available at the DHN are known from Equations (23) and (24). Then, Equations (25)-(27) state that the boiler and the HP production must meet the remaining heat demand, if any. Furthermore, Equations (27) and (28) require that the electrical chillers or reversible heat pumps meet the chilled water demand, and Equation (29) defines the electrical energy exchange with the grid. Therefore, as mentioned, the nine decision variables are bound to each other and the problem is conveniently reduced to finding the dispatch priority order and the optimal ICE load factor $L_{I C E}$ that minimize the cost of energy at each timestep. Eleven discrete values of $L_{I C E}$ have been considered, and an exhaustive search algorithm was adopted to identify the optimal solution, among all the possible combinations. This allows the development of a low computational-cost algorithm, compatible with the need for a quick response for real-time implementation [30] and further advanced analyses (e.g., optimal design and uncertainty analysis, as in [29]).

\section{Results and Discussion}

Figure 5 shows the total annual costs depending on the nominal electrical capacity of the CHP unit. We note that the optimal CHP size is practically the same for both of the configurations $\left(75 \mathrm{~kW}_{\mathrm{el}}\right)$, 
with a total cost reduction of about $8 \%$ for the distributed solution. Economic details are presented in Table 4. The size of all generators are shown in Table 5.

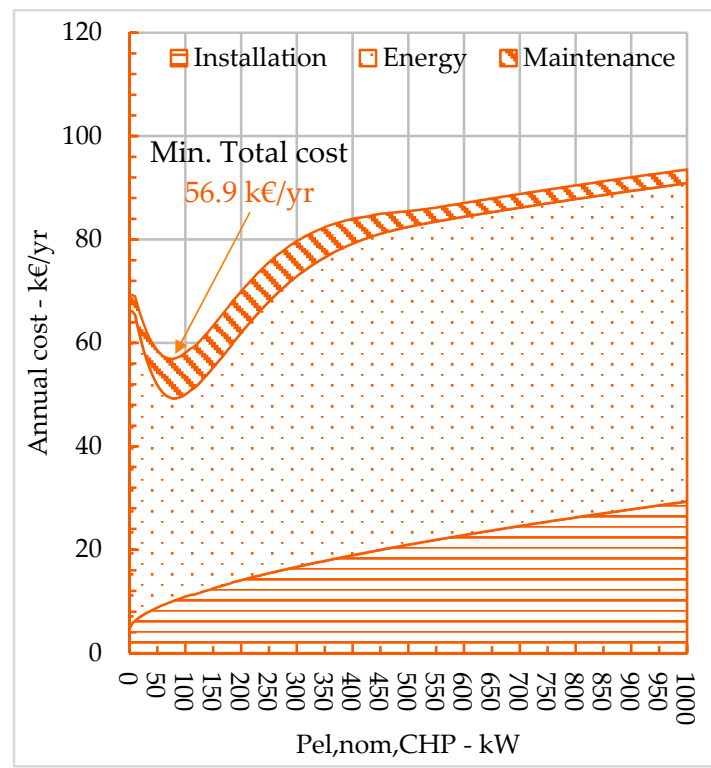

(a) Distributed configuration.

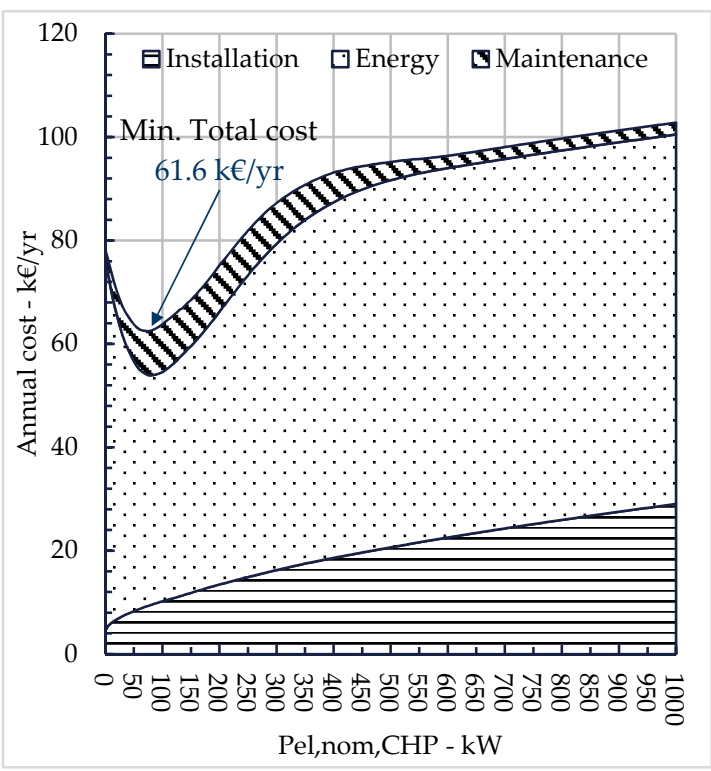

(b) Centralized configuration.

Figure 5. Installation, energy, and maintenance annual costs using the optimal control strategy.

Table 4. Annual costs of the optimal distributed and centralized configurations, $\mathrm{k} € / \mathrm{yr}$.

\begin{tabular}{|c|c|c|}
\hline Tag & Distributed Configuration & Centralized Configuration \\
\hline$P E C_{I C E}$ & 5.2 & 5.2 \\
\hline$P E C_{H P}$ & 4.2 & - \\
\hline$P E C_{C}$ & - & 3.5 \\
\hline$P E C_{B}$ & 0.5 & 0.6 \\
\hline Total & 9.9 & 9.3 \\
\hline$O C_{I C E}$ & 35.8 & 45.1 \\
\hline$O C_{B}$ & 2.1 & 5.7 \\
\hline$O C_{e l, P}$ & 7.1 & 4.5 \\
\hline$O C_{e l, S}$ & -5.6 & -11.4 \\
\hline Total & 39.4 & 43.8 \\
\hline$O \& M$ & 7.6 & 8.5 \\
\hline Total Cost & 56.9 & 61.6 \\
\hline
\end{tabular}

Table 5. Optimal sizes for the distributed and centralized configurations, kW.

\begin{tabular}{|c|c|c|c|}
\hline Units & Tag & Distributed Configuration & Centralized Configuration \\
\hline \multirow{3}{*}{ CHP } & $P_{\text {el,nom }}$ & 75 & 75 \\
\hline & $P_{\text {th,nom }}$ & 107 & 107 \\
\hline & $\mathrm{P}_{\text {in,nom }}$ & 200 & 200 \\
\hline \multirow{2}{*}{ HPs } & $\mathrm{P}_{\text {th,H,nom }}$ & 370 & - \\
\hline & $P_{\text {th,C,nom }}$ & - & 323 \\
\hline Chillers & $P_{\text {th,C,nom }}$ & - & 323 \\
\hline Boilers & $\mathrm{P}_{\text {th,nom }}$ & 150 & 180 \\
\hline
\end{tabular}

Figure 6 shows some examples of the heat and power profiles resulting from the optimization procedure in three weeks of the year for the distributed configuration. In addition to the areas and lines explained in the chart legend, we specify that the white area under the blue curve in the thermal plots represents the thermal overproduction by the CHP unit; the white area under the green, orange, or yellow lines in the electricity plots quantifies the electrical energy sold to the grid. 


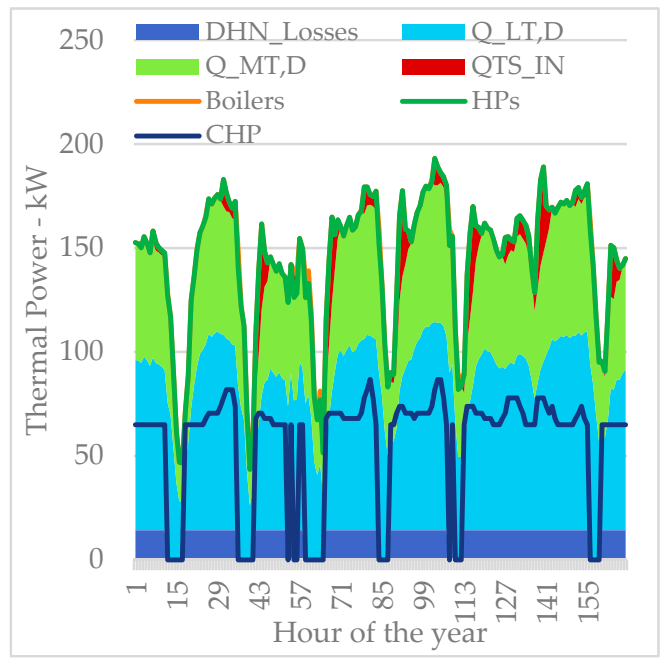

(a)1st week of January

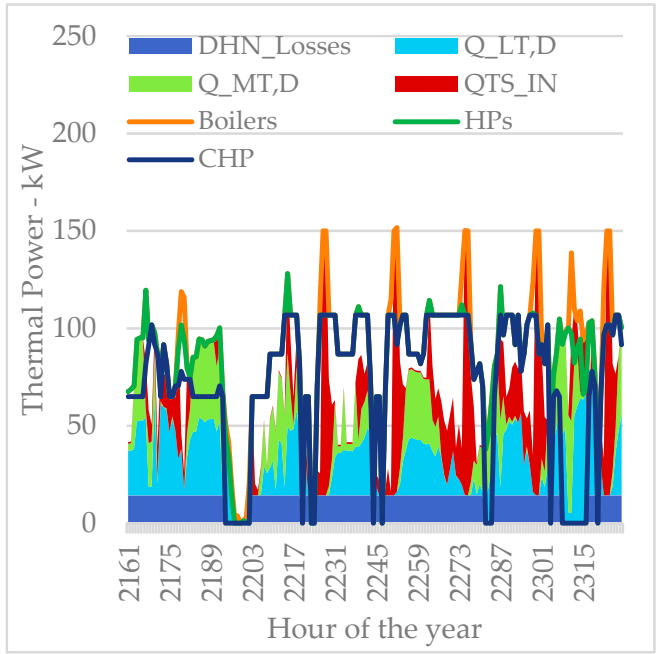

(c)1st week of April

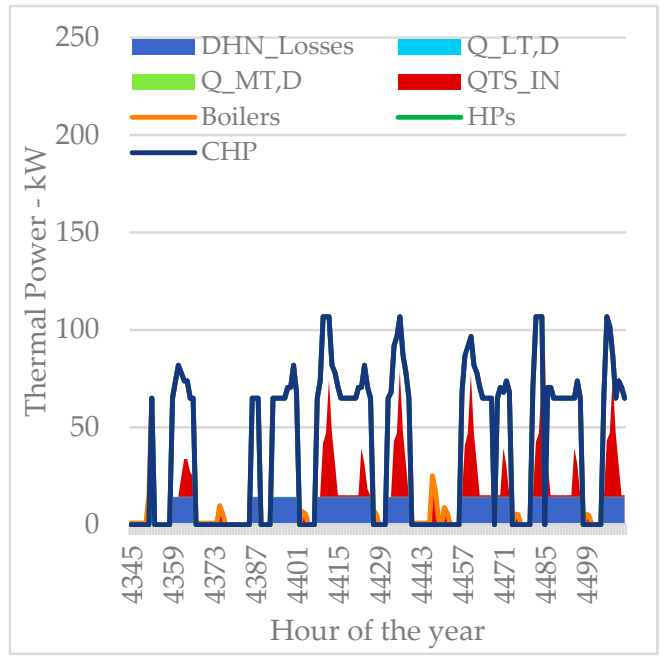

(e)1st week of July

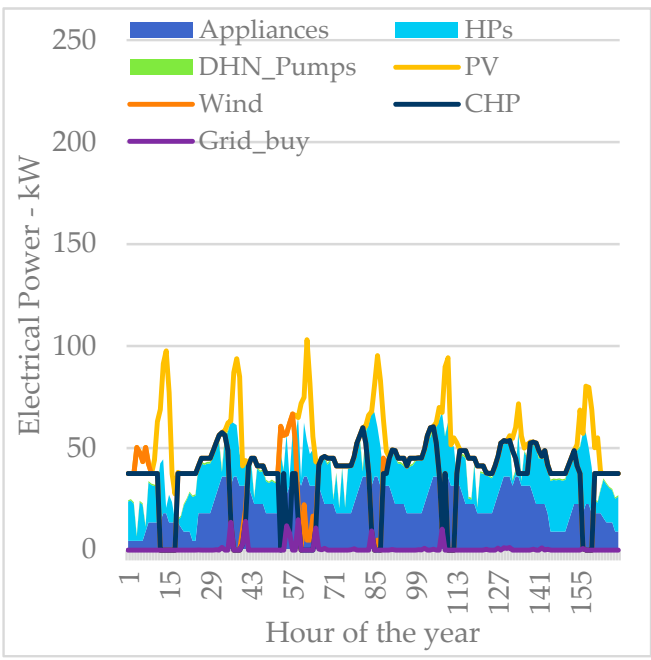

(b)1st week of January

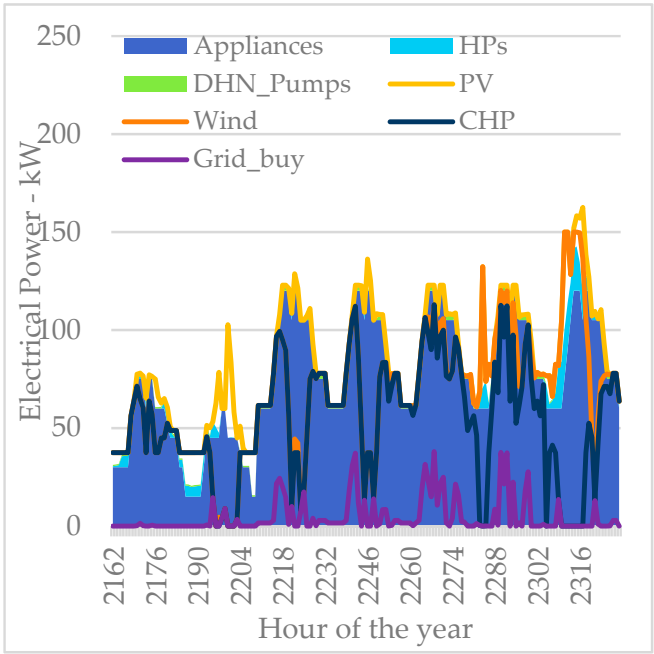

(d)1st week of April

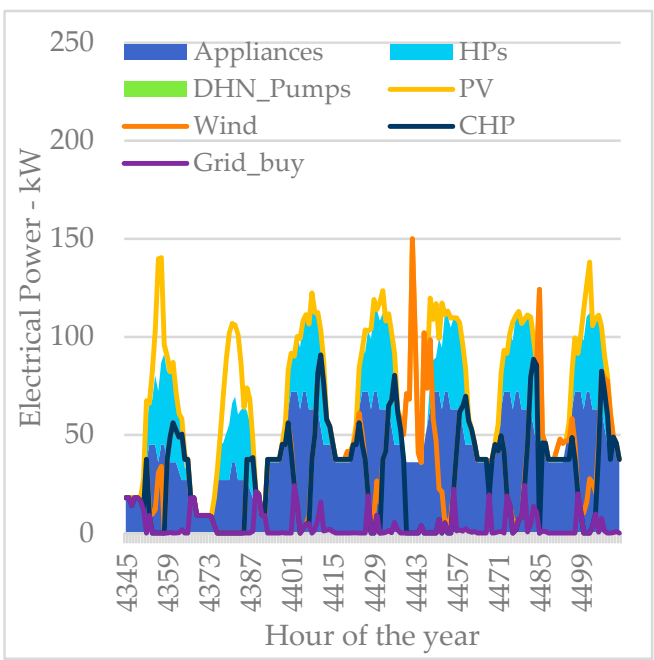

(f)1st week of July

Figure 6. Heat and power profiles in 3 weeks of the year (areas are for consumption, lines for production). 
The CHP delivers the base load during the winter season and the heat pumps meet the heating demand. The boilers are rarely used as the electricity produced by the renewables sources and CHP is enough to run the heat pumps. During the mid-seasons, the CHP mainly meets the high electricity demand of the appliances. The HPs are rarely used as it is more convenient to use the boilers to meet the few thermal peaks with respect to purchasing more electrical energy from the grid. In summer, the CHP still operates at high load factors to meet the residual electrical load from the variable solar and wind production. The thermal overproduction mainly occurs during the mid and summer seasons because it is more convenient to maximize the electrical production of the CHP unit, with respect to purchasing electricity from the grid.

The annual values reported in Figures 7 and 8 highlight the energy and economic advantages of the distributed configuration. The distributed configuration reduces both the DHN thermal losses and the CHP overproduction ( $-27 \%$ and $-9 \%$, respectively), thus, reducing the overall thermal energy production $(-6 \%)$. The heat pumps deliver about $24 \%$ of the heating load and the boilers reduce their output to about $68 \%$. In the centralized configuration, the CHP unit delivers $77 \%$ of the thermal load, being more cost-effective than the gas boiler. However, the corresponding total electricity production (CHP, $\mathrm{PV}$, and wind generator) is significantly greater than the electrical load, resulting in an unprofitable overproduction (about $28 \%$ of the total electricity production is sold to the grid at an uneconomical price). On the contrary, the introduction of the heat pumps shifts part of the thermal load to the electrical one, increasing the self-consumption of electricity and reducing both the CHP energy production ( $-20 \%$ of thermal and $-21 \%$ of electrical energy, respectively) and the power sold to the grid $(-51 \%)$. In total, the presence of the HPs reduces the power exchange with the electrical grid from 259 to $159 \mathrm{MWh}(-40 \%)$ considering both sold and purchased quantities.

Although the objective function of the optimization process refers to an economic index, the energy and the environmental benefits of the distributed configuration are shown in Table 6. The net no-RES primary energy consumption was reduced by about $8 \%$, and the equivalent $\mathrm{CO}_{2}$ emissions were reduced by about $11 \%$. These values were evaluated considering the primary energy factors and the specific $\mathrm{CO}_{2}$ emissions of the Italian energy systems [31,32]. According to a grid perspective, the energy system can be thought of as an electricity generator with a specific emission of $232 \mathrm{~g} / \mathrm{kWh}$ in the distributed configuration and $238 \mathrm{~g} / \mathrm{kWh}$ in the centralized one. We note that the average value of specific $\mathrm{CO}_{2}$ emissions for Italian power production is about $313 \mathrm{~g} / \mathrm{kWh}$.

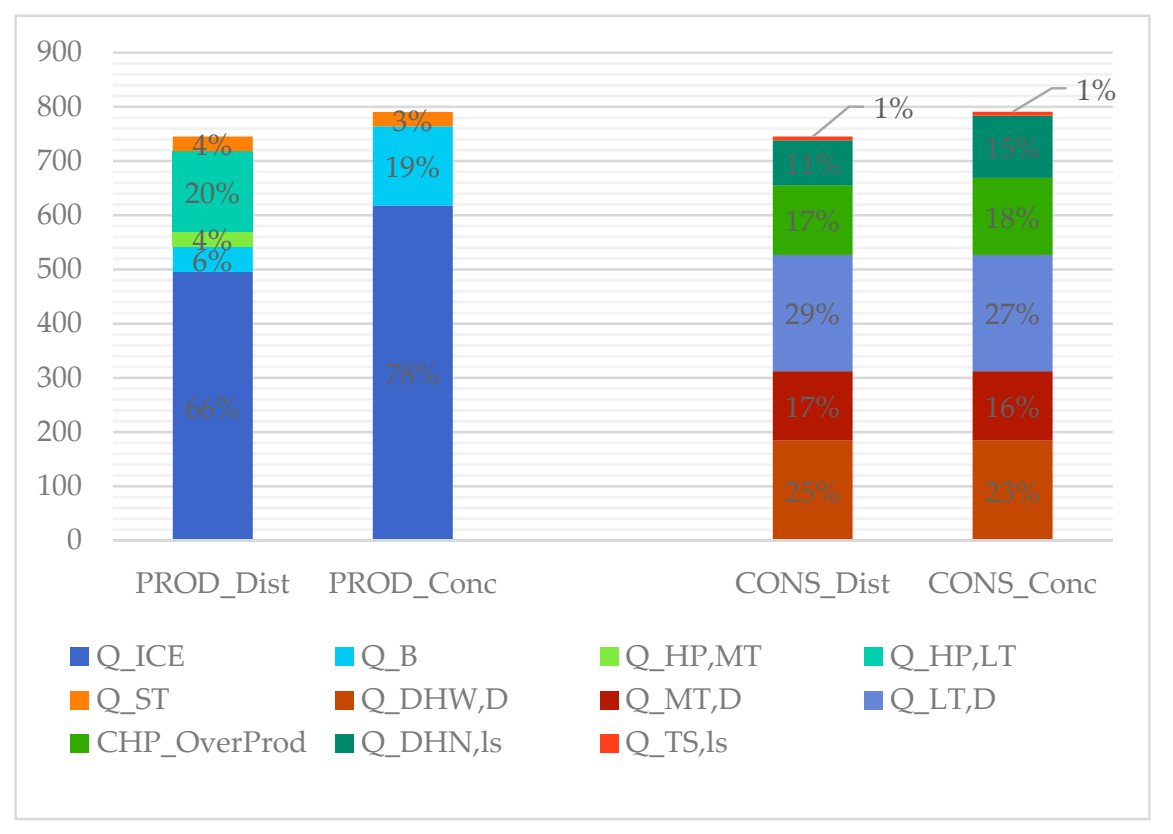

Figure 7. Thermal energy balance (MWh/yr). 


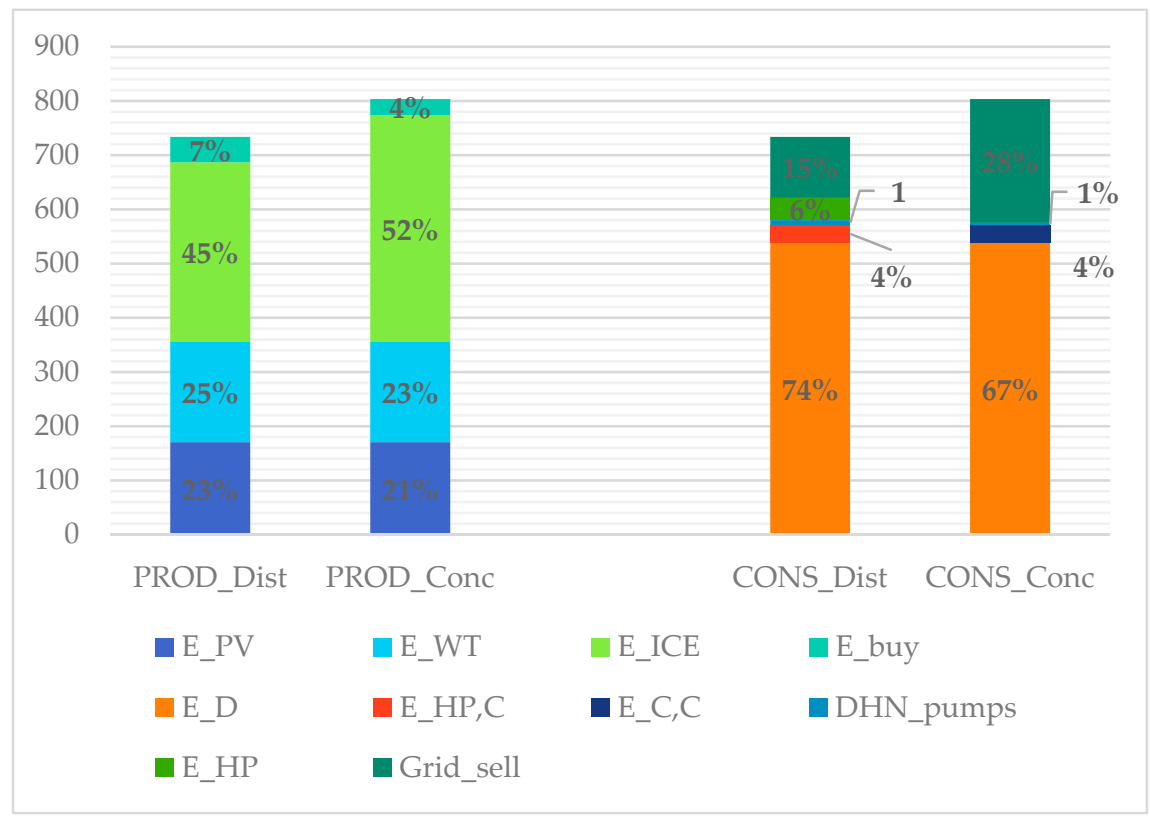

Figure 8. Electrical energy balance (MWh/yr).

Table 6. Energy and environmental performance indexes.

\begin{tabular}{cccccc}
\hline $\mathbf{M W h} / \mathbf{y r}$ & Value & Value & ton/yr & Value & Value \\
\hline EP $_{\text {no-RES,IN,CHP }}$ & 940.3 & 1182.6 & $\mathrm{CO}_{2, \mathrm{CHP}}$ & 180.86 & 227.47 \\
$\mathbf{E P}_{\text {no-RES,IN,,Boilers }}$ & 54.8 & 148.6 & $\mathrm{CO}_{2, \text { Boilers }}$ & 10.55 & 28.58 \\
EP $_{\text {no-RES,IN,Grid }}$ & 91.8 & 58.8 & $\mathrm{CO}_{2, \text { Grid }}$ & 15.31 & 9.81 \\
EP $_{\text {no-RES,OUT,Grid }}$ & -218.6 & -445.7 & $\mathrm{CO}_{2, \text { Grid }}$ & -36.45 & -74.33 \\
TOT EP $_{\text {no-RES,IN }}$ & $\mathbf{8 6 8 . 3}$ & $\mathbf{9 4 4 . 4}$ & TOT CO $_{\mathbf{2}}$ & $\mathbf{1 7 0 . 2 6}$ & $\mathbf{1 9 1 . 5 3}$ \\
\hline
\end{tabular}

Overall, the results show that the proposed hybrid centralized-distributed configuration outperforms the more conventional centralized configuration from an economic, environmental, and efficiency perspectives. Indeed, the introduction of heat pumps at the building level enhances the operational flexibility of the system by enabling the interconnection between the thermal and electric networks. In this way, RES-based energy production can be used mainly on-site-instead of being sold to the regional grid-and the use of inefficient technologies, such as natural-gas boilers, can be drastically reduced.

\section{Conclusions}

An innovative configuration for smart multi-energy microgrids serving clusters of buildings has been presented. The energy system combines both centralized and distributed generation units, optimally integrating cogeneration-based micro-district heating, RES technologies, and reversible heat pumps.

The proposed system was tested in a hypothetical case study, namely, a University Campus located in Trieste (Italy). A detailed modeling of the building load demands, district heating network, and all energy units has been provided in order to simulate the energy system in a reference-year scenario. Moreover, an operational optimization algorithm was specifically developed to identify the generator scheduling that meets the energy demand while minimizing the operational cost. The optimal size of the cogeneration unit and reversible heat pumps has also been found.

The proposed configuration was compared to a more conventional layout based completely on centralized heat production. The results show how the introduction of distributed heat pumps to assist the thermal production at the building level enhances the flexibility and cost-effectiveness of the 
energy system. Indeed, an $8 \%$ total-cost saving, $11 \%$ carbon emission reduction, and $8 \%$ primary energy saving were achieved compared to the centralized reference case. Moreover, the proposed configuration significantly reduced the electric energy exchange with the regional grid (around $40 \%$ less).

Future work will address the current limitations of the work: the optimal sizing of the whole system will be investigated, the effect of uncertainty in weather conditions and economic parameters will be analyzed, and the effectiveness of energy storage managed by predictive control will be evaluated.

Author Contributions: Conceptualization, D.T.; Data curation, D.T., P.C., E.S., L.U. and F.D.; Methodology, D.T., P.C., E.S., L.U. and F.D.; Software, D.T., P.C., E.S., L.U. and F.D. Supervision, D.T.; Writing-original draft, D.T., P.C., E.S., L.U. and F.D.; Writing-review \& editing, D.T., P.C., E.S., L.U. and F.D.

Funding: This research was funded by the University of Pisa (PRA 2017-18, Grant n. 33).

Acknowledgments: We would like to thank our colleagues at the University of Pisa involved in energy systems integration activities, who contributed to the discussion and development of the mathematical and engineering models, with a special acknowledgement to Professors Marco Raugi, Davide Poli, Davide Aloini, and Antonio Frangioni.

Conflicts of Interest: The authors declare no conflict of interest.

\section{Nomenclature}

\begin{tabular}{|c|c|}
\hline \multicolumn{2}{|c|}{ Acronyms } \\
\hline $\mathrm{CHP}$ & Combined Heat and Power \\
\hline $\mathrm{DHN}$ & District Heating Network \\
\hline DHW & Domestic Hot Water \\
\hline ICE & Internal Combustion Engine \\
\hline INV & Investment \\
\hline O\&M & Operations and Maintenance \\
\hline PEC & Purchased Equipment Cost \\
\hline RES & Renewable Energy Sources \\
\hline \multicolumn{2}{|c|}{ Parameters } \\
\hline c & Cost, $€ / \mathrm{kWh}$ \\
\hline $\mathrm{COP}$ & Coefficient of performance, dimensionless \\
\hline OC & Annual operational cost, $€$ \\
\hline TC & Total annual energy cost, $€$ \\
\hline UA & Overall heat transfer coefficient, $\mathrm{kW} / \mathrm{K}$ \\
\hline$\eta$ & Efficiency, dimensionless \\
\hline \multicolumn{2}{|c|}{ Continuous variables } \\
\hline $\mathrm{C}$ & Cooling energy, kWh \\
\hline $\mathrm{E}$ & Electric energy, kWh \\
\hline $\mathrm{F}$ & Energy content of the consumed fuel, $\mathrm{kWh}$ \\
\hline $\mathrm{L}$ & Load factor, dimensionless \\
\hline $\mathrm{P}$ & Power, kW \\
\hline Q & Thermal energy, kWh \\
\hline$S$ & Surface, $\mathrm{m}^{2}$ \\
\hline $\mathrm{T}$ & Temperature, ${ }^{\circ} \mathrm{C}$ \\
\hline $\mathrm{U}$ & Global heat transfer coefficient, $\mathrm{kW} /\left(\mathrm{m}^{2} \cdot \mathrm{K}\right)$ \\
\hline V & Volume, $\mathrm{m}^{3}$ \\
\hline $\mathrm{w}$ & Wind speed, $\mathrm{m} / \mathrm{s}$ \\
\hline$\lambda$ & Thermal Conductivity, $\mathrm{kW} /(\mathrm{m} \cdot \mathrm{K})$ \\
\hline$\rho$ & Density, $\mathrm{kg} / \mathrm{m}^{3}$ \\
\hline
\end{tabular}




$\begin{array}{ll}\text { Subscripts } & \\ \text { avg } & \text { Average } \\ \text { aux } & \text { Auxiliary } \\ \text { B } & \text { Boiler } \\ \text { ICE } & \text { Internal combustion engine } \\ \text { C } & \text { Chiller } \\ \text { D } & \text { Demand } \\ \text { DHN } & \text { District Heating Network } \\ \text { el } & \text { Electric } \\ \text { EC } & \text { Electric Chiller } \\ \text { ext } & \text { External } \\ \text { F } & \text { Fuel } \\ \text { HP } & \text { Heat Pump } \\ \text { HT } & \text { High-temperature level } \\ \text { i } & \text { i-th hourly timestep } \\ \text { j } & \text { j-th building with DHW requirements } \\ \text { k } & \text { k-th building with heating/cooling requirements } \\ \text { Ls } & \text { Losses } \\ \text { LT } & \text { Low-temperature level } \\ \text { MT } & \text { Medium-temperature level } \\ \text { P } & \text { Purchased } \\ \text { PEG } & \text { Electricity purchased by the grid } \\ \text { PV } & \text { Photovoltaic } \\ \text { ref } & \text { Reference } \\ \text { S } & \text { Sold } \\ \text { ST } & \text { Solar Thermal } \\ \text { SEG } & \text { Electricity sold to the grid } \\ \text { th } & \text { Thermal } \\ \text { TS } & \text { Thermal Storage } \\ \text { w } & \text { Water } \\ \text { WT } & \text { Wind Turbine } \\ \text { Superscripts } & \\ \text { Nom } & \text { Nominal } \\ \text { II } & \text { Second-law } \\ & \end{array}$

\section{References}

1. European Parliament and Council. Directive 2012/27/EU on Energy Efficiency; European Parliament and Council: Brussels, Belgium, 2012.

2. European Parliament and Council. Directive 2010/31/EU on the Energy Performance of Buildings; European Parliament and Council: Brussels, Belgium, 2010.

3. Pagliarini, G.; Rainieri, S. Modeling of a thermal energy storage system coupled with combined heat and power generation for the heating requirements of a University Campus. Appl Therm. Eng. 2010, 30, 1255-1261. [CrossRef]

4. Bracco, S.; Delfino, F.; Pampararo, F.; Robba, M.; Rossi, M. The University of Genoa smart polygeneration microgrid test-bed facility: The overall system, the technologies and the research challenges. Renew. Sustain. Energy Rev. 2013, 18, 442-459. [CrossRef]

5. Piacentino, A.; Barbaro, C.; Cardona, F.; Gallea, R.; Cardona, E. A comprehensive tool for efficient design and operation of polygeneration-based energy $\mu$ grids serving a cluster of buildings. Part I: Description of the method. Appl. Energy 2013, 111, 1104-1121.

6. Piacentino, A.; Barbaro, C. A comprehensive tool for efficient design and operation of polygeneration-based energy $\mu$ grids serving a cluster of buildings. Part II: Analysis of the applicative potential. Appl. Energy 2013, 111, 1122-1138. 
7. Destro, N.; Benato, A.; Stoppato, A.; Mirandola, A. Components design and daily operation optimization of a hybrid system with energy storages. Energy 2016, 117, 569-577. [CrossRef]

8. Murphy, M.D.; O'Mahony, M.J.; Upton, J. Comparison of control systems for the optimisation of ice storage in a dynamic real time electricity pricing environment. Appl. Energy 2015, 149, 392-403. [CrossRef]

9. Roldán-Blay, C.; Escrivá-Escrivá, G.; Roldán-Porta, C.; Álvarez-Bel, C. An optimisation algorithm for distributed energy resources management in micro-scale energy hubs. Energy 2017, 132, 126-135. [CrossRef]

10. Phan, Q.A.; Scully, T.; Breen, M.; Murphy, M.D. Determination of optimal battery utilization to minimize operating costs for a grid-connected building with renewable energy sources. Energy Convers. Manag. 2018, 174, 157-174. [CrossRef]

11. Asleye, D.A.; Breen, M.; Murphy, M.D. A decision support tool for building integrated renewable energy microgrids connected to a smart grid. Energies 2017, 10, 1765. [CrossRef]

12. Fischer, D.; Madani, H. On heat pumps in smart grids: A review. Renew. Sustain. Energy Rev. 2017, 70, 342-357. [CrossRef]

13. Grassi, W.; Conti, P.; Schito, E.; Testi, D. Solutions to improve energy efficiency in HVAC for renovated buildings. In Handbook of Energy Efficiency in Buildings; Asdrubali, F., Desideri, U., Eds.; Elsevier: Amsterdam, The Netherlands, 2019; Chapter 9.3.

14. Ebrahimi, M.; Keshavarz, A. Combined Cooling Heating and Power: Decision-Making, Design and Optimization; Elsevier: Amsterdam, The Netherlands, 2015.

15. Evans, D.L. Simplified method for predicting photovoltaic array output. Sol. Energy 1981, 27, 555-560. [CrossRef]

16. Duffie, J.A.; Beckman, W.A. Solar Engineering of Thermal Processes, 4th ed.; John Wiley \& Sons, Inc.: Hoboken, NJ, USA, 2013.

17. Burton, T.; Sharpe, D.; Jenkins, N.; Bossanyi, E. Wind Energy Handbook; John Wiley \& Sons: Hoboken, NJ, USA, 2002.

18. CEN. Heating Systems in Buildings-Method for Calculation of System Energy Requirements and System Efficiencies-Part 4-2: Space Heating Generation Systems, Heat Pump Systems; EN 15316-4-2; CEN: Brussels, Belgium, 2008.

19. O'Callaghan, P.W.; Probert, S.D. Sol-air temperature. Appl. Energy 1977, 3, 307-311. [CrossRef]

20. CEN. Energy performance of buildings. In Overall Energy Use and Definition of Energy Ratings; EN 15306; CEN: Brussels, Belgium, 2008.

21. Testi, D.; Schito, E.; Conti, P. Cost-optimal sizing of solar thermal and photovoltaic systems for the heating and cooling needs of a nearly Zero-Energy Building: Design methodology and model description. Energy Procedia 2016, 91, 517-527. [CrossRef]

22. Testi, D.; Rocca, M.; Menchetti, E.; Comelato, S. Criticalities in the NZEB retrofit of scholastic buildings: Analysis of a secondary school in Centre Italy. Energy Procedia 2017, 140, 252-264. [CrossRef]

23. CTI (Italian Thermotechnical Committee). National Typical Meteorological Years; CTI: Milan, Italy, 2016.

24. Bejan, A.; Tsatsaronis, G.; Moran, M. Thermal Design and Optimization; Wiley: Hoboken, NJ, USA, 1995.

25. Paradigma Catalogue. 2018. Available online: http://www.paradigmaitalia.it/sites/default/files/2018-03/ lp_041_rev.00_listino_compact_power_2018_3.pdf (accessed on 18 February 2019).

26. Energy Efficiency Report, Politecnico di Milano. 2013. Available online: http://www.energystrategy.it/ report/efficiency-report.html (accessed on 18 February 2019).

27. Renewable Energy Report, Politecnico di Milano. 2018. Available online: http://www.energystrategy.it/ report/renewable-energy-report.html (accessed on 18 February 2019).

28. CEN. Energy Performance of Buildings-Overall Energy Use and Definition of Energy Ratings; EN 15459-1; Annex, D., Ed.; CEN: Brussels, Belgium, 2017.

29. Urbanucci, L.; Testi, D. Optimal integrated sizing and operation of a CHP system with Monte Carlo risk analysis for long-term uncertainty in energy demands. Energy Convers. Manag. 2018, 157, 307-316. [CrossRef]

30. Urbanucci, L.; Testi, D. An operational optimization method for a complex polygeneration plant based on real-time measurements. Energy Convers. Manag. 2018, 170, 50-61. [CrossRef] 
31. D.M. 26-06-2015-Applicazione delle metodologie di calcolo delle prestazioni energetiche e definizione delle prescrizioni e dei requisiti minimi degli edifici; Adeguamento del decreto del Ministro dello sviluppo economico, 26 giugno 2009-Linee guida nazionali per la certificazione energetica degli edifici (In Italian). Available online: https:/ / www.mise.gov.it/index.php/it/normativa/decreti-interministeriali/2032966-decretointerministeriale-26-giugno-2015-applicazione-delle-metodologie-di-calcolo-delle-prestazioni-energetiche-edefinizione-delle-prescrizioni-e-dei-requisiti-minimi-degli-edifici (accessed on 22 February 2019).

32. ISPRA. Fattori di Emissione Atmosferica di Gas a Effetto Serra e Altri Gas nel Settore Elettrico; ISPRA: Roma, Italy, 2018. (In Italian) article distributed under the terms and conditions of the Creative Commons Attribution (CC BY) license (http:/ / creativecommons.org/licenses/by/4.0/). 